Article

\title{
Undocumented Migration and Electoral Support: Evidence From Spain
}

\author{
Ismael Gálvez-Iniesta and José L. Groizard* \\ Department of Applied Economics, University of the Balearic Islands, Spain; E-Mails: i.galvez@uib.es (I.G.-I.), \\ joseluis.groizard@uib.es (J.L.G.) \\ * Corresponding author
}

Submitted: 16 April 2021 | Accepted: 16 June 2021 | Published: 28 October 2021

\begin{abstract}
Unwrapping the political discourse against immigration is key to understanding the rise of populism in Western democracies. A growing body of literature has found ample evidence that immigration pays a premium to conservative political forces that propose tighter policies. Using data on presidential elections in Spain from 2008 to 2019, we shed light on this debate by highlighting the role played by irregular migration. Some studies show that undocumented immigrants consume less and earn lower wages than documented immigrants with similar observable characteristics. In addition, since they are relegated to working in the informal sector, they cannot contribute to the welfare state with direct taxes. This suggests that undocumented migration might intensify support for right-wing politics and that the effect is independent from the one caused by the presence of documented migrants. We apply an instrumental variable strategy to deal with the non-random distribution of migrants across political districts. Our findings indicate that increasing undocumented migration increases support for the right, while increasing documented migration rises support for the left. When we consider the irruption of the far-right into electoral competitions, we find that undocumented migration redistributes votes from the left to the right, as has been observed in other countries.
\end{abstract}

\section{Keywords}

extreme right; immigration; instrumental variables; political economy; undocumented migration; voting

\section{Issue}

This article is part of the issue "Migration and Refugee Flows: New Insights" edited by Inmaculada Martínez-Zarzoso (University of Göttingen, Germany / Jaume I University, Spain).

(C) 2021 by the authors; licensee Cogitatio (Lisbon, Portugal). This article is licensed under a Creative Commons Attribution 4.0 International License (CC BY).

\section{Introduction}

Unwrapping the political discourse against immigration has become key to understanding the growing wave of populism that has hit Western democracies in the last decade. In the 2016 US presidential election, Donald Trump proposed the construction of a border wall to fight against illegal entry into the country. More recently, on a single day in May 2021, an unprecedented number of 8,000 individuals illegally crossed the Spain-Morocco border in Ceuta. Spain's new far-right political party, VOX, classified the event as an invasion, and the centerright Popular Party (PP) claimed that Spain's territorial integrity was threatened by the entry of illegal immigrants. In Europe, it is certainly common to find far-right parties that oppose immigration and have broad support among voters (Dennison \& Geddes, 2019): the National Front in France, the Northern League in Italy, the Dutch Freedom Party, and the United Kingdom Independence Party in the UK, just to name a few. The political divide around immigration in Europe reached its peak with the so-called "refugee crisis" in the summer of 2015. Large immigration shocks, including those caused by asylum seekers and massive border crossings, cause concern among political parties. Those on the extreme right frequently use the visibility given by the media to these episodes to promote anti-immigration messages, exacerbating xenophobic sentiments.

The literature has dealt with the economic and non-economic effects of immigration considering several 
dimensions: natives' employment and wages (Card, 2001; Peri, 2016), public finances (Dustmann \& Frattini, 2014; Preston, 2014), gains from cultural diversity (Ottaviano \& Peri, 2005), criminality (Alonso-Borrego et al., 2012; Chalfin, 2014), and natives' attitudes towards immigrants (Mayda, 2006). More recently, a rising number of studies are documenting that immigration is affecting voting behavior, with different outcomes. Mendez and Cutillas (2014) provide evidence that immigration led to more relative electoral support for the left than for the right in presidential elections in Spain. However, other studies have shown that immigration is favoring far-right political parties in national elections (e.g., for Italy, Barone et al., 2016; for France, Edo et al., 2019; for Austria, Halla et al., 2017; and for Greece, Roupakias \& Chletsos, 2020) or the Republican Party in the US when it embraced anti-immigration discourse (Mayda et al., 2020).

Motivated by the so-called "Iberian exceptionalism" (Dennison \& Mendes, 2019), this article analyzes the role of immigration, both documented and undocumented, in shaping voters' political preferences in Spain. We make use of both terms, regular and irregular, as synonyms for documented and undocumented immigrants, respectively, since both are found in the literature. The main contribution of this article is that it studies the effects that immigration has on voting, differentiating between regular and irregular immigrants. Spanish voters are often exposed (via considerable media attention) to dramatic episodes of illegal border crossings at sea. The traditional literature provides us with general ideas on the underlying mechanisms through which immigrants affect natives' welfare. However, with few exceptions, legal status is absent from the discussion and, therefore, the way in which irregular immigration shapes voters' opinions is still an unexplored field.

It has been shown that some immigrant characteristics vary with legal status. For example, Dustmann et al. (2017) provide evidence that, once conditioned on background characteristics, undocumented immigrants consume $40 \%$ less than documented immigrants. These lower levels of consumption are likely the consequence of lower incomes and a higher risk of being deported. Similarly, Albert (2021) shows that, in the labor market, undocumented immigrants earn conditionally lower wages and have higher job-finding rates than documented immigrants and natives. As irregular immigrants are expelled from the formal sector, they are relegated to work in worse conditions than natives (and regular immigrants). Gálvez-Iniesta (2020) documents that irregular immigrants in Spain are disproportionally concentrated in low-wage sectors such as those related to hospitality, food service, and household activities. To understand the labor market impact of irregular immigration, Albert (2021) uses a job search model where natives and immigrants are perfect substitutes, inducing a strong competition effect. He quantitatively explores the consequences of an immigration shock, uses a model to make estimations, and finds that an increase in the number of undocumented migrants enhances natives' wages and employment, while an increase in documented immigration decreases the native employment rate and has an ambiguous effect on wages. Thus, undocumented migrants hardly harm voters' jobs or wages, and relaxing the perfect substitutes assumption leads to even more job creation.

On the other hand, voters might reject irregular immigration to the extent that it places a tax burden on them since these immigrants cannot contribute to the direct financing of public services that they are entitled to enjoy, such as education and public health, a claim often made by far-right parties. In Spain, documented and undocumented immigrants acquire the right to access health and education services when they register in local municipal registers. Using data from the UK, Dustmann and Preston (2007) found that welfare concerns play a larger role in determining attitudes about immigration than concerns over wages or employment. According to the most recent wave of the survey Attitudes Towards Immigration (2017), carried out by the Spanish Sociological Research Center (CIS), 55\% of Spaniards believe that immigrants receive more from the public system than they contribute. Around $20 \%$ said that immigrants receive as much as they contribute and only $9 \%$ believe that their contribution is greater than their benefit. Understanding how these opinions are formed is not a straightforward task, given the methodological challenges associated with accounting for individuals' net contributions to public finances and the fact that the limited number of studies on this topic do not support such claims (Collado et al., 2004; OECD, 2013). On the other hand, it is likely that these figures simply reflect the scope of the anti-immigration messages pushed by anti-redistribution parties.

A different approach to the issue involves assessing the extent to which irregular immigrants sort into areas where the public provision of public services is scarce. That is, voters might respond negatively to immigration not due to the fiscal burden imposed on natives, but to the lack of supply of public services in the neighborhoods where irregular migrants settle (Rickardsson, 2021). A natural way to estimate how much tax revenue is lost due to irregular migration is to evaluate amnesty programs. In this regard, Monras et al. (2020) document that payroll tax revenue increased yearly by 4,000 euros per each newly legalized immigrant after the 2005 regularization carried out by the socialist party (PSOE) in Spain. This suggests that the cost of implementing an amnesty program will be overcome by the large increase in tax revenues.

Voters may have non-economic reasons to reject illegal migration. A common argument has to do with the changing value of compositional amenities in neighborhoods after an immigration shock. Halla et al. (2017) provide evidence that natives care about the quality of schooling since children have to commute longer 
distances to schools and parents have fewer childcare options in areas where the share of immigrants is higher. This type of argument applies to both documented and undocumented immigrants without distinction, and it becomes an issue when the geographic distribution of irregular migrants differs from regular ones, as will be shown below. A different approach emphasizes the role of cultural identity and locally provided public goods. For example, voters might perceive the presence of irregular migrants on the streets as a threat to their cultural identity, reinforcing xenophobia sentiments, given that almost half of the irregular population is made up of immigrants from African (Morocco and Sub-Saharan Africa) and Non-EU Eastern European countries, all of whom have different languages and ethnic traits, and many of whom have different religious practices. Alternatively, illegal immigration might stoke natives' fears that the immigrants will carry out criminal activities. Although the literature on immigration and criminality is inconclusive, some evidence reveals a causal relationship between undocumented immigrants in Spain and drug trafficking (Mccully, 2020).

Last but not least, moderate voters might reject irregular immigration, including border crossings, simply because of the belief that the rule of law, as a national public good, should prevail over other humanitarian principles and that international labor flows should be regulated. However, the enforcement of immigration rules is an imperfect task undertaken by governments, and illegal entry is, to some extent, inevitable. To this end, voters might perceive that the implementation of immigration amnesties has a magnet effect that might lead to out-of-control migration in the future. However, Monras et al. (2020) and Orrenius and Zavodny (2003) are unable to find changes in long-term patterns of undocumented immigration after the implementation of two significant amnesty programs in Spain (2005) and in the US (1986), respectively.

Thus, the presence of irregular immigrants might intensify economic and non-economic channels and may have discernible effects on voting behavior that would be independent from those caused by regular immigrants. Provided that the differential impact of irregular immigration is mostly non-economic, anti-immigration politics are likely to be grounded in the supply of xenophobia. As Glaeser (2005) emphasizes, anti-redistribution politicians have incentives to spread unfounded hate-inspiring stories about poor minorities simply because their opponents support policies that benefit minorities.

We present evidence that migrants' legal statuses affect political outcomes across the political spectrum. As in Dustmann et al. (2019) and in Roupakias and Chletsos (2020) we explore the conjecture that immigration divides society into extreme groups and examine which parties might stand to gain and which might stand to lose. We find that an increase in the share of irregular migrants increases the share of votes to the conservative party but has no impact on the vote share of the PSOE. However, voters respond to rising regular migration the other way around, favoring the PSOE and having no effect on the vote share of the right. Our results are in sharp contrast with those from Mendez and Cutillas (2014) who found that immigration favored left political parties over right political parties in electoral contests held between 1996 and 2011. We include new political forces, such as VOX, to test the role played by immigration and national-identity discourse in the general elections that took place after the refugee crisis of 2015. Our results indicate that, after considering the increased political competition, greater proportions of irregular immigrants produce a change in the distribution of the share of votes from the left to the right. In contrast, greater proportions of regular immigrants reduce support for the right and the far-right, although the parties on the left do not seem to benefit from this. That is, our results indicate that the right has capitalized on the narrative of restricting irregular migration. We shed light on the controversy and find that Spaniards did not act much differently than their European counterparts.

\section{Background}

\subsection{Historical Context}

Spain has migration figures similar to other advanced economies. The share of foreign-born residents is $13 \%$, not far from the proportions seen in Italy (10\%), France $(12 \%)$, the UK or Germany (13\%), and the US (15\%), though it remains below levels seen in Switzerland, Australia, Canada, and Sweden. From a historical perspective, however, Spain differs from these developed economies in two salient ways. On the one hand, during the 20th century Spain experienced large-scale episodes of emigration to Latin American countries and Europe. On the other hand, the current migration rate is the result of a very high inflow that has occurred over just one or two decades, while migration in other countries responds to more parsimonious processes.

Spain is an interesting case to study for several reasons. First, it plays an important role in the context of European migration given its prominent geographical location as a border country with the African continent; thus, it has to deal with a constant pressure to control illegal border crossers aimed at reaching other European countries. Moreover, the common historical roots shared with Latin American and Arabic countries makes Spain a preferred destination for immigrants from many developing countries. Secondly, Spain's immigration policy is one of the most active at the bilateral level; it is targeted to control irregular flows both in countries of origin and along the migrants' routes towards Europe, and it establishes special legal procedures for immigrants from certain countries of origin. Thirdly, a stable political consensus between Spain's two major political parties, one on the left (PSOE) and one on the right (PP), has dominated Spanish immigration policy in recent decades. For 
example, since 1985, Spain has implemented six regularizations of undocumented immigrants, carried out with indifference to which of the two aforementioned political parties were in power. The first regularization took place between 1985 and 1986, and was followed by others in 1991, 1996, 2000, 2001, and 2005. Most of these processes were aimed at regularizing workers who could demonstrate their roots in Spain; however, at times they have been extended to other categories of migrants such as families (1996, 2000, and 2001), asylum seekers (2000), or specific nationalities, such as that which occurred in 2001 with Ecuadorian citizens. The most important regularization was undertaken by the PSOE in 2005. Fourthly, until the arrival of a far-right political party, VOX, in 2015, the anti-immigration political discourse was subtle and did not garner significant political support. It is not clear what role the anti-immigration rhetoric exerted by VOX leaders played in its electoral success, especially at a time during which two salient issues dominated the political battlefield: the numerous corruption scandals plaguing the center-right PP and the unfriendly bout for independence undertaken by the regional authorities in Catalonia. Both issues may have played a major role in explaining the recent incursion of a populist radical right party. Lastly, after a steady downward trend in the incidence of irregularity (mainly due to the previously mentioned regularizations and the emergence of the Great Recession), the number of irregular immigrants has increased by a factor of six since 2013 and has recently accelerated with the political crisis afflicting Venezuela, which has also increased the number of asylum seekers.

Although de facto the PP and the PSOE broadly share a consensus on how to manage migration inflows, their narratives during electoral contests have been quite different. For example, in 2006 the number of irregular immigrants arriving in the Canary Islands by boat (i.e., cayuco) reached an unprecedented 39,180 migrants. The PP proposed, during the 2008 electoral campaign, a contract of integration whereby immigrants would commit to respecting Spanish customs and in the event of long-term unemployment, they would return to their countries of origin. Simultaneously, the ruling party at the time, the PSOE, was able to curb the number of arrivals in Spain by signing direct agreements with the immigrants' countries of origin.

\subsection{Data}

Migration policies are defined at the national level, and therefore we focus on presidential elections. We collect data on the outcomes of the elections that took place in 2008, 2011, 2015, 2016, and 2019 at the province level. Two presidential elections took place in 2019, first in April and then again in November. As our main explanatory variables (regular and irregular immigrant share) are calculated yearly, we restrict our analysis to the most recent election (November). Spain is divided into 50 provinces and two autonomous cities (Ceuta and Melilla), each of which are electoral districts. We restrict the sample to provinces from 2008 onwards. The reason for this is that the previous presidential election, in 2004, falls very near 2002, which is the base year for the instrument used to calculate the share of immigration (see Section 4). Data on votes was taken from the Spanish Ministry of the Interior. The dataset records the number of registered votes, valid and invalid. We compute shares of votes for the main political parties (PSOE, PP, Podemos, and VOX) by dividing the number of votes cast for each party by the number of valid votes. In Subsection 5.2 we split the political parties based on their ideologies (right-wing for PP and VOX, left-wing for PSOE and Podemos).

The number of regular immigrants is given as the number valid residence permits in each province granted to non-EU immigrants. The data was collected from the Spanish Ministry of Social Security and Migrations, which also provided the information on the number of residences permits in each province for each foreign nationality. This is key to constructing our instrument for regular and irregular migration, as explained below. As EU workers can legally reside (and work) in Spain without the need for a residence permit, we refer to regular immigrants as non-EU immigrants legally residing in the country. That is, our measure of regular immigrants does not include EU nationalities.

To the extent that irregular immigrants are by definition not entitled to live in a country, the estimation of the size of the irregular immigrant population in a country is not straightforward. However, Spain constitutes a unique case for delivering high-quality estimates of irregular immigration, as it provides high incentives for all immigrants (regardless of their legal status) to enroll in local population registers. Precisely, irregular immigrants are encouraged to register to obtain health benefits (Bertoli \& Fernández-Huertas Moraga, 2013) and because they can use this as proof of residence for later regularization. This institutional feature allows us to apply the residual method (as per, Gálvez-Iniesta, 2020; González Ferrer \& Cebolla Boado, 2008) to estimate the total count of irregular migrants by subtracting the number of valid residence permits held by non-EU migrants from the total number of non-EU migrants enrolled in the local population registers.

Despite this feature of Spanish law, applying the residual method is not free from limitations. First, it is common that people leaving the country do not unregister from local population registers, leading to overestimates of the irregular population. To tackle this issue, since 2003, the foreign-born population without permanent residence permits must renew their enrollment every two years (Izquierdo et al., 2015; Jandl et al., 2008), which makes our estimates more reliable. Secondly, the naturalization of immigrants may put an upward bias on the estimation, as those granted Spanish nationality would be dropped from the number of people with valid residence permits (since they do not need it 
anymore) but it would take time for the local registers to update their legal statuses. Notice that these limitations mainly introduce temporary imbalances, which could affect the accuracy of the year-point estimator. However, as explained in the next subsection, our empirical strategy relies on long-term changes in the size of the irregular population, as we look at changes between electoral cycles (i.e., every four years). Therefore, small year-to-year disparities do not represent a serious threat to our identification strategy.

In the estimation we add a battery of controls, including the unemployment rate, the share of population by age group (less than 25, prime-age (25-64), and older than 65), and the share of workers by sector of activity and education level (less than high school degree (high-school dropouts), at least high-school degree but without college (intermediate-educated), and college graduates). The data was obtained from the Spanish Labor Force Survey. We also control for the average income per capita, using the GDP per capita as reported by the Spanish Regional Accounts.

Table 1 shows descriptive statistics. By construction, the share of non-EU immigrants is given by the sum of regular and irregular immigrants. In the five election years considered, the average of the provincial immigration share was around $9.5 \%$ of the total population. The share of non-EU immigrants was $5.36 \%$. That is, around $56 \%$ of immigrants were from non-EU coun- tries. Most of these are classified as regular immigrants: the share of regular (non-EU) immigrants was 4.7\%, while the share of irregular immigrants is the remaining $0.6 \%$. In other words, for the years under consideration, irregular immigrants accounted for around $11 \%$ of all non-EU immigrants.

We take advantage of regional variations in changes in the share of regular and irregular immigrants. To illustrate this regional variation, we built heat maps of the Spanish provinces: For each province, we plotted the average change in the share of regular (Figure 1) and irregular immigrants (Figure 2) from each of the two consecutive election years considered in the estimation. A comparison of the two figures clearly illustrates that the effect of regular and irregular immigrants can potentially be very different. The increase in the share of regular migrants was particularly notable in the south and along the Mediterranean coast. In contrast, changes in the share of irregular immigrants were concentrated in provinces in the center and the northwest, and to some extent, the northeast of the country. The disparity between changes in the share of regular and irregular immigrants is particularly striking in southern and southeastern Spain.

To shed light on the relevance of irregular migration, in Figure 3 we plot the correlation between the changes in the share of each two immigration types and changes in the log of the ratio of votes for the PSOE over the PP. We use this ratio as a dependent variable to replicate the

Table 1. Descriptive statistics.

\begin{tabular}{|c|c|c|c|c|c|}
\hline & Obs. & Mean & Std. dev & Min & Max \\
\hline Share of total immigrants (\%) & 250 & 9.49 & 5.40 & 2.4 & 24.3 \\
\hline$\Delta$ Share of total immigrants & 200 & -0.15 & 1.37 & -5.7 & 2.6 \\
\hline Share of non-EU immigrants (\%) & 250 & 5.36 & 3.21 & 1.2 & 15.3 \\
\hline$\Delta$ Share of non-EU immigrants & 200 & 0.09 & 0.85 & -2.3 & 2.2 \\
\hline Share of regular immigrants (\%) & 250 & 4.73 & 2.90 & 1.2 & 13.5 \\
\hline$\Delta$ Share of total immigrants & 200 & -0.01 & 0.43 & -1.6 & 1.7 \\
\hline Share of irregular immigrants (\%) & 250 & 0.62 & 0.77 & -1.5 & 3.0 \\
\hline$\Delta$ Share of total immigrants & 200 & 0.10 & 0.57 & -1.4 & 1.5 \\
\hline PP vote share (\%) & 250 & 36.19 & 13.17 & 4.9 & 64.2 \\
\hline PSOE vote share $(\%)$ & 250 & 30.00 & 9.39 & 12.4 & 58.1 \\
\hline VOX vote share (\%) & 113 & 6.84 & 8.52 & 0.1 & 27.9 \\
\hline PODEMOS vote share (\%) & 150 & 16.20 & 5.56 & 5.4 & 30.9 \\
\hline$\Delta$ Share of PP votes & 200 & -4.26 & 13.25 & -34.5 & 43.7 \\
\hline$\Delta$ Share of PSOE votes & 200 & -3.61 & 8.56 & -31.3 & 10.6 \\
\hline$\Delta$ Share of VOX votes & 58 & 9.43 & 9.39 & -0.2 & 27.6 \\
\hline$\Delta$ Share of PODEMOS votes & 100 & -3.46 & 4.77 & -14.4 & 5.3 \\
\hline Log ratio PSOE over PP & 250 & -0.15 & 0.44 & -1.1 & 1.2 \\
\hline Change in log ratio PSOE over PP & 200 & 0.04 & 0.50 & -1.7 & 0.9 \\
\hline$\Delta$ Unemployment rate & 200 & 0.77 & 6.12 & -9.8 & 15.3 \\
\hline$\Delta$ Log GDP per capita & 200 & 0.02 & 0.09 & -0.3 & 0.2 \\
\hline$\Delta$ Share of younger than 25 & 200 & -0.34 & 0.44 & -1.2 & 0.6 \\
\hline$\Delta$ Share of older than 65 & 200 & 0.62 & 0.44 & -0.4 & 1.9 \\
\hline$\Delta$ Share of high school dropouts & 200 & -3.68 & 3.53 & -27.5 & 5.4 \\
\hline$\Delta$ Share of college graduates & 200 & 1.68 & 1.86 & -3.8 & 7.6 \\
\hline$\Delta$ Share of workers in agriculture & 200 & -0.49 & 158.95 & -650.0 & 760.0 \\
\hline
\end{tabular}




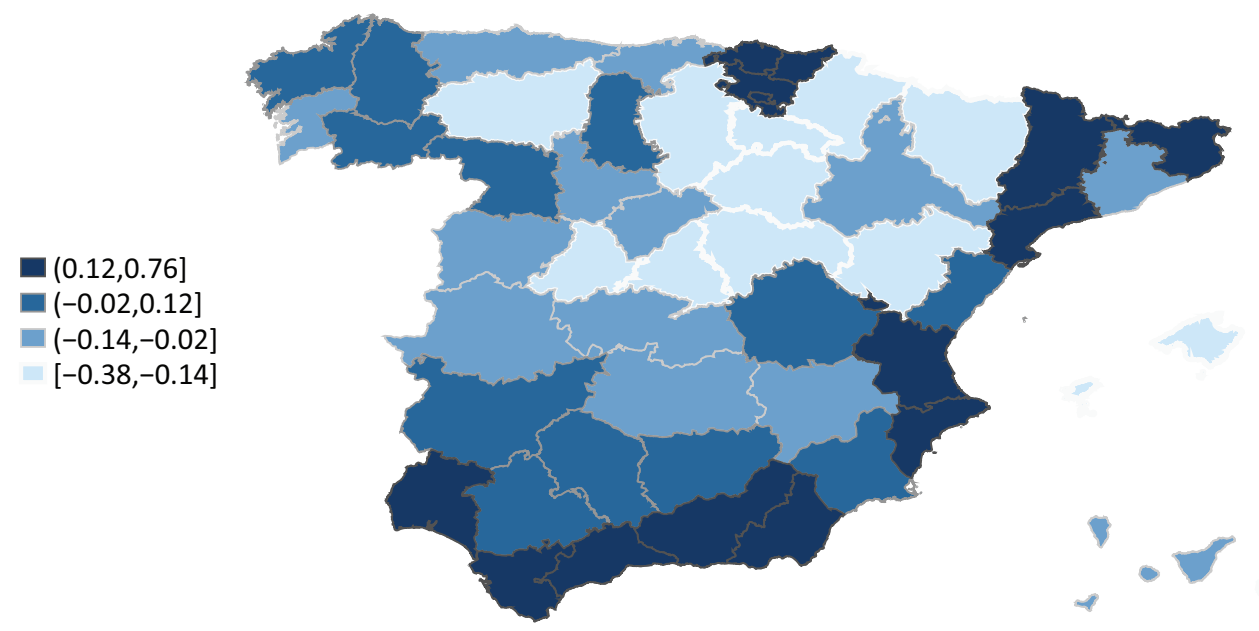

Figure 1. Average increase in the share of regular immigrants from two consecutive presidential election years (2008-2019).

results of Mendez and Cutillas (2014). Consistent with their work, the left panel of the figure suggests that an increase in the share of regular immigrants is associated with an increase in support for the major leftist party over the major conservative party. In contrast, when we replicate the same analysis with changes in the share of irregular immigrants, we find evidence of close-to-zero correlation. These figures should be viewed with caution, as changes in the share of regular and irregular immigrants are far from exogenous, which prevent us from claiming causality. However, they make very clear the that the sign of the effect of irregular immigration can be very different from the standard estimates found in previous literature. In the next section we further examine the causal effect of immigration on voting by instrumenting our main regressors.

\section{Empirical Strategy}

We start by proposing a simple equation to estimate the impact of immigration on vote shares. We model the change of the vote share for party $p$ at election occurred at time $t$ in electoral district $i$ as follows:

$$
\begin{aligned}
\Delta \text { vote }_{i t}^{p}= & \beta_{R}^{p} \Delta\left(\frac{\text { Regular }_{i t}}{\operatorname{Pop}_{i t}}\right)+\beta_{l}^{p} \Delta\left(\frac{\text { Irregular }_{i t}}{\text { Pop }_{i t}}\right) \\
& +\Delta X_{i t}^{\prime} \delta^{p}+\lambda_{t}^{p}+\Delta \varepsilon_{i t^{p}}^{p}
\end{aligned}
$$

where $\left(\operatorname{Regular}_{i t} / \mathrm{Pop}_{i t}\right)$ and $\left(\operatorname{Irregular}_{i t} / \mathrm{Pop}_{i t}\right)$ are regular and irregular immigrant shares of the population in province $i$ at time $t$. The difference operator indicates changes between electoral years. By taking differences in the model, we assume that idiosyncratic, time-invariant fixed effects that determine the vote are removed, and by introducing time fixed effects we account for aggregate shocks that vary from election to election and affect voting patterns in all political districts simultaneously. A set of economic and demographic controls at the province level $\left(X_{i t}\right)$ are also included to account for other changes that might determine political support. Note that a province is an administrative division that is fairly equivalent to a local labor market (e.g., Donoso et al.,
(0.19,0.36]

ㅁ $0.11,0.19$

$\square(0.03,0.11]$

$[-0.20,0.03]$

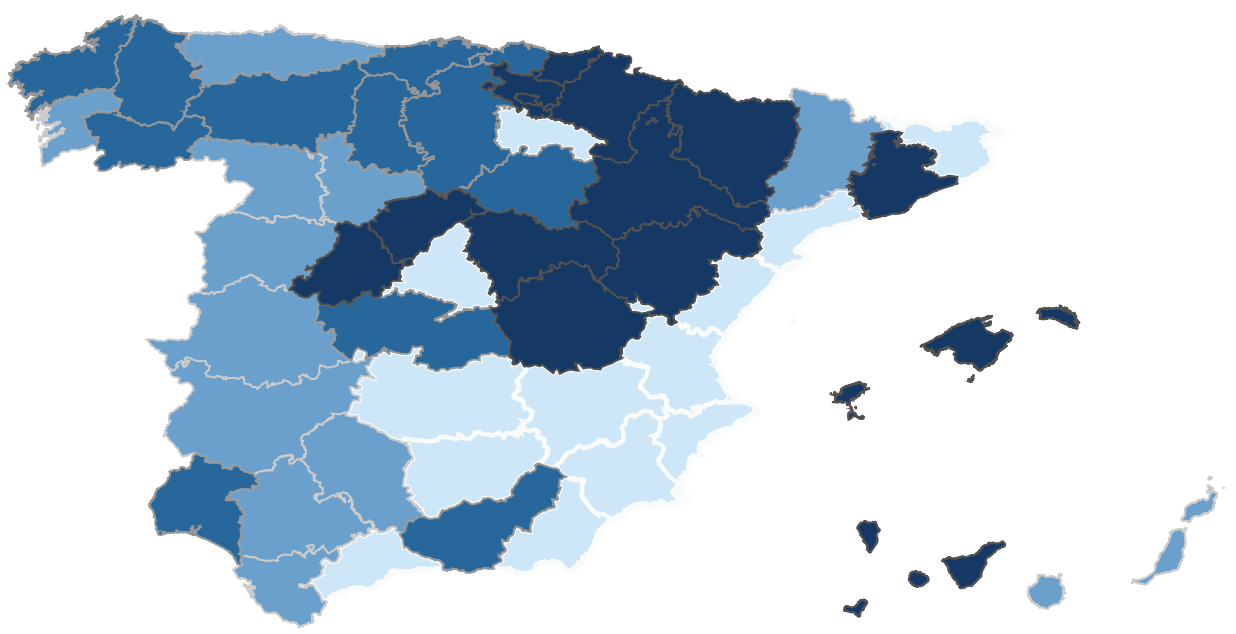

Figure 2. Average increase in the share of irregular immigrants from two consecutive presidential election years (2008-2019). 

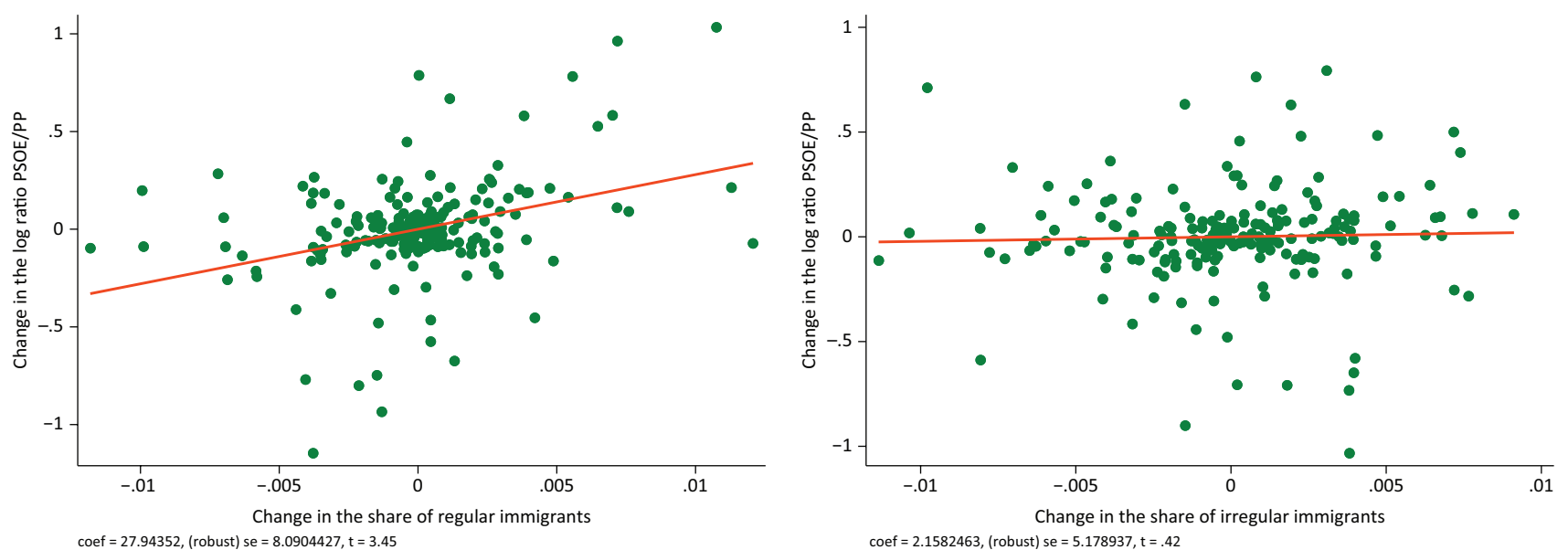

Figure 3. Scatter plot of changes in the share of regular and irregular immigrants against the changes in the log of the ratio of votes for the PSOE over the PP.

2015; González \& Surovtseva, 2020). The standard errors from the estimated parameters of Equation 1 need to be adjusted for clustering at the province level to control for possible serial correlation. Spain's 17 autonomous communities are divided into 50 provinces. We use provincelevel clustering instead of clustering the standard errors at the autonomous community-level because of the high levels of heterogeneity within some autonomous communities in terms of voting behavior, shares of immigrants, and many of the control variables included in the specification. However, as a robustness check, we also run the estimation with the standard errors clustered at the autonomous community-level, and the results barely change.

From a methodological point of view, we have to deal with the fact that the distribution of migrants across political districts is not random and, therefore, unobservable determinants of voting captured in the error term $\left(\varepsilon_{i t}^{p}\right)$ are likely to be correlated with the shares of regular or irregular migrants. Thus, simple OLS estimates of the parameters of interest $\left(\beta_{R}^{p}, \beta_{l}^{p}\right)$ would lead to erroneous inferences. To be more precise, there are two main reasons why OLS estimates are likely biased. First, migrants might locate systematically in provinces where voters prefer left-wing parties or reject right-wing political options. Secondly, it is also plausible that both migration decisions to locate in a province and political attitudes to vote are driven by common economic or demographic factors. To address these concerns, we rely on an instrumental variables (IV) approach.

The source of identification takes advantage of regional variations in the change of regular and irregular migrations which are unrelated to other political or economic changes that affect voting at the district-level once other shocks are controlled for. Our identification strategy benefits from the fact that changes in regular and irregular migration shares are, in general, differentiated spatially, as shown in Figures 1 and 2. We, therefore, instrument recent migration inflows by the settlement patterns across electoral districts and country of nation- ality in 2002 interacted with the subsequent national inflow of immigrants from each country. Given that we are considering two groups of immigrants by legal status, we build one instrument per category. This method was popularized by Card (2001) and is widely used in the literature (e.g., Edo et al., 2019; Mayda et al., 2020; Mendez \& Cutillas, 2014).

Let us define $\widehat{Z}_{i t}$ as the shift-share projection of variable $Z_{i t}$, with $Z_{i t}=\left\{\right.$ Regular $_{i t}$, Irregular $\left._{i t}\right\}$ being a different immigrant group defined as follows:

$$
\widehat{Z}_{i t}=\sum_{c}\left(\frac{Z_{c i, 2002}}{Z_{i, 2002}}\right) \Delta Z_{c t},
$$

where the term in the parenthesis is the proportion of immigrants of nationality $c$ residing in province $i$ in the base year, 2002, and $\Delta Z_{c t}$ is the national inflow of immigrants from origin country $c$ in election year $t$ after the base year.

The instrument for the share of $Z_{i t}$ in the total population is the simple ratio of $\widehat{Z}_{i t}$ over the total predicted population (i.e., including national residents and both regular and irregular immigrants). The predicted population is also obtained using the same shift-share principle. We end up with two instruments, one for the share of regular immigrants ( Regular $_{i t} / \widehat{\text { Pop }}_{i t}$ ) and another for the share of irregular immigrants $\left(\operatorname{Irregular}_{i t} / \widehat{\mathrm{Pop}}_{i t}\right)$. The instruments used in our model as differences are, therefore,

$$
\Delta\left(\frac{\widehat{Z}_{i t}}{{\widehat{\mathrm{Pop}_{i t}}}_{i t}}\right)=\left(\frac{\widehat{Z}_{i t}}{\widehat{\mathrm{Pop}}_{i t}}\right)-\left(\frac{\widehat{Z}_{i t-1}}{\widehat{\mathrm{Pop}_{i t-1}}}\right) \text {. }
$$

\section{Results}

\subsection{Immigration and Votes for the Two Major Political Parties}

Table 2 reports the OLS estimates of the effect of changes in the share of regular and irregular immigrants on the 
change in the vote share for the PP, for various specifications. In Column 1 we do not control for year fixed effects, while in Columns 2 to 6 we control for year fixed effects and sequentially add different controls, which allows us to understand the impact of the inclusion of each control variable on the estimation of the coefficients of interest. All standard errors are clustered at the province level. Column 6 shows the results obtained from the baseline estimation (i.e., with all controls) of Equation 1. The OLS estimates indicate that irregular immigration is not significantly correlated with changes in the share of votes for the $\mathrm{PP}$, while regular immigration is negatively correlated and significant at the $5 \%$ level (and only at the $10 \%$ level in the baseline estimation: Column 6 , with all controls).

As explained in the previous section, the OLS estimates cannot be used to infer causality, as regular and irregular immigrants are not randomly distributed across provinces. In Table 3 we use the same specifications as in Table 2 and provide the IV estimates of Equation 1. The bottom panel of Table 3 provides the KleibergenPaap rk Wald F statistics: For all the specifications our results indicate that we can clearly reject the null that our IV estimates suffer from a weak instrument problem (Stock et al., 2002). According to the IV estimates, an increase in the share of irregular immigrants has a positive and significant impact on the share of votes for the PP. In contrast to this result, the effect of an increase in the share of regular immigrants is negative and is not significant. The magnitude of the estimated coefficient on the share of irregular immigration implies that a $1 \%$ increase in the share of irregular immigrants increases the share of votes for the PP by 5 to $6 \%$. As we see in Column 1, if we do not control for time-varying unobserved effects, we would overestimate the absolute effect of both regular and irregular immigrants. Moving from Column 2 to 6 we can see that the result is robust to the inclusion of all sets of controls. We find that the OLS estimates of the impact of irregular immigration on the vote share of the PP is biased downward. Finding a larger effect when using IV instead of OLS is consistent with the idea that irregular immigrants are more likely to migrate to provinces where the vote share for PP is decreasing.

Now, considering the IV impact of immigration on votes for the PSOE (Table 5), we find that a $1 \%$ increase in the share of regular immigrants produces an increase in the vote share of the PSOE of $3.1 \%$. In contrast, the estimated effect of irregular immigration is not significant. The results are robust to including demographic and socioeconomic characteristics of provinces as controls (Columns 2-6). The IV estimates based on irregular migration are lower (as well as negative and not significant) than the corresponding OLS estimates (which are positive and significant, see Table 4), suggesting that where irregular immigrants choose to settle is not

Table 2. OLS impact of immigration on the share of votes for the PP.

\begin{tabular}{|c|c|c|c|c|c|c|}
\hline & (1) & (2) & (3) & (4) & (5) & (6) \\
\hline$\Delta$ Share of irregular immigrants & $\begin{array}{l}-0.141 \\
(1.807)\end{array}$ & $\begin{array}{c}3.034 \\
(1.998)\end{array}$ & $\begin{array}{c}3.224 \\
(1.997)\end{array}$ & $\begin{array}{c}2.675 \\
(2.124)\end{array}$ & $\begin{array}{c}2.706 \\
(2.146)\end{array}$ & $\begin{array}{c}2.918 \\
(2.268)\end{array}$ \\
\hline$\Delta$ Share of regular immigrants & $\begin{array}{l}-3.136 \\
(3.258)\end{array}$ & $\begin{array}{c}-6.979 * * \\
(2.996)\end{array}$ & $\begin{array}{l}-7.426^{* *} \\
(2.959)\end{array}$ & $\begin{array}{l}-6.728^{* *} \\
(3.106)\end{array}$ & $\begin{array}{c}-6.693^{* *} \\
(3.112)\end{array}$ & $\begin{array}{l}-6.736^{* *} \\
(3.189)\end{array}$ \\
\hline$\Delta$ Unemployment rate & & & $\begin{array}{c}0.00364 \\
(0.00400)\end{array}$ & $\begin{array}{c}0.00317 \\
(0.00378)\end{array}$ & $\begin{array}{c}0.00394 \\
(0.00383)\end{array}$ & $\begin{array}{c}0.00292 \\
(0.00368)\end{array}$ \\
\hline$\Delta$ Log GDP per capita & & & $\begin{array}{c}-0.0408^{*} \\
(0.0220)\end{array}$ & $\begin{array}{c}-0.0852 * \\
(0.0427)\end{array}$ & $\begin{array}{c}-0.0902 * * \\
(0.0436)\end{array}$ & $\begin{array}{c}-0.0928 * * \\
(0.0443)\end{array}$ \\
\hline$\Delta$ Share of younger than 25 & & & & $\begin{array}{c}5.949 * \\
(3.519)\end{array}$ & $\begin{array}{c}5.944 \\
(3.564)\end{array}$ & $\begin{array}{c}6.192 * \\
(3.580)\end{array}$ \\
\hline$\Delta$ Share of older than 65 & & & & $\begin{array}{c}-0.405 \\
(1.894)\end{array}$ & $\begin{array}{c}-0.0136 \\
(1.878)\end{array}$ & $\begin{array}{c}0.199 \\
(1.919)\end{array}$ \\
\hline$\Delta$ Share of high school dropouts & & & & & $\begin{array}{c}-0.145 \\
(0.165)\end{array}$ & $\begin{array}{c}-0.137 \\
(0.180)\end{array}$ \\
\hline$\Delta$ Share of highly educated & & & & & $\begin{array}{c}0.318 \\
(0.304)\end{array}$ & $\begin{array}{c}0.262 \\
(0.296)\end{array}$ \\
\hline$\Delta$ Share of workers in agriculture & & & & & & $\begin{array}{c}-0.00201 \\
(0.00385)\end{array}$ \\
\hline$\Delta$ Share of workers in construction & & & & & & $\begin{array}{c}-0.00448 \\
(0.00633)\end{array}$ \\
\hline$\Delta$ Share of workers in industry & & & & & & $\begin{array}{c}-0.00242 \\
(0.00507)\end{array}$ \\
\hline Year FE & NO & YES & YES & YES & YES & YES \\
\hline $\mathrm{N}$ & 200 & 200 & 200 & 200 & 200 & 200 \\
\hline
\end{tabular}

Notes: The dependent variable is the change in the share of votes for the PP between two consecutive presidential elections. Regressions are run at the province level. Standard errors are clustered at the province level and reported in parenthesis. Significance levels are denoted by $* * * p<0.01, * * p<0.05, * p<0.1$. 
Table 3. IV impact of immigration on the share of votes for the PP.

\begin{tabular}{|c|c|c|c|c|c|c|}
\hline & (1) & $(2)$ & (3) & (4) & (5) & (6) \\
\hline$\Delta$ Share of irregular immigrants & $\begin{array}{l}6.253^{* * *} \\
(2.093)\end{array}$ & $\begin{array}{l}5.959 * * \\
(2.341)\end{array}$ & $\begin{array}{l}5.639 * * \\
(2.259)\end{array}$ & $\begin{array}{l}5.075^{* *} \\
(2.315)\end{array}$ & $\begin{array}{l}4.941^{* *} \\
(2.278)\end{array}$ & $\begin{array}{l}5.403^{* *} \\
(2.599)\end{array}$ \\
\hline$\Delta$ Share of regular immigrants & $\begin{array}{l}-9.834 * * * \\
(3.609)\end{array}$ & $\begin{array}{l}-3.104 \\
(2.094)\end{array}$ & $\begin{array}{c}-3.530 * \\
(2.085)\end{array}$ & $\begin{array}{l}-2.337 \\
(1.951)\end{array}$ & $\begin{array}{l}-2.436 \\
(2.082)\end{array}$ & $\begin{array}{l}-2.340 \\
(2.096)\end{array}$ \\
\hline$\Delta$ Unemployment rate & & & $\begin{array}{c}0.00306 \\
(0.00386)\end{array}$ & $\begin{array}{c}0.00249 \\
(0.00357)\end{array}$ & $\begin{array}{c}0.00331 \\
(0.00361)\end{array}$ & $\begin{array}{c}0.00214 \\
(0.00343)\end{array}$ \\
\hline$\Delta$ Log GDP per capita & & & $\begin{array}{c}-0.0408^{*} \\
(0.0220)\end{array}$ & $\begin{array}{c}-0.0849 * \\
(0.0438)\end{array}$ & $\begin{array}{l}-0.0901^{* *} \\
(0.0445)\end{array}$ & $\begin{array}{c}-0.0922 * * \\
(0.0447)\end{array}$ \\
\hline$\Delta$ Share of younger than 25 & & & & $\begin{array}{c}6.233^{*} \\
(3.627)\end{array}$ & $\begin{array}{c}6.238^{*} \\
(3.632)\end{array}$ & $\begin{array}{c}6.556 * \\
(3.579)\end{array}$ \\
\hline$\Delta$ Share of older than 65 & & & & $\begin{array}{c}-0.848 \\
(1.673)\end{array}$ & $\begin{array}{c}-0.437 \\
(1.623)\end{array}$ & $\begin{array}{c}-0.126 \\
(1.645)\end{array}$ \\
\hline$\Delta$ Share of high school dropouts & & & & & $\begin{array}{c}-0.147 \\
(0.166)\end{array}$ & $\begin{array}{c}-0.147 \\
(0.185)\end{array}$ \\
\hline$\Delta$ Share of highly educated & & & & & $\begin{array}{c}0.335 \\
(0.293)\end{array}$ & $\begin{array}{c}0.274 \\
(0.286)\end{array}$ \\
\hline$\Delta$ Share of workers in agriculture & & & & & & $\begin{array}{c}-0.00205 \\
(0.00369)\end{array}$ \\
\hline$\Delta$ Share of workers in construction & & & & & & $\begin{array}{c}-0.00588 \\
(0.00627)\end{array}$ \\
\hline$\Delta$ Share of workers in industry & & & & & & $\begin{array}{c}-0.00138 \\
(0.00429)\end{array}$ \\
\hline Year FE & NO & YES & YES & YES & YES & YES \\
\hline K.-P. rk Wald F statistic & 9.407 & 11.59 & 15.62 & 20.78 & 18 & 11.67 \\
\hline $\mathrm{N}$ & 200 & 200 & 200 & 200 & 200 & 200 \\
\hline
\end{tabular}

Notes: The dependent variable is the change in the share of votes for the PP between two consecutive presidential elections. Significance levels are denoted by ${ }^{* * *} \mathrm{p}<0.01,{ }^{* *} \mathrm{p}<0.05,{ }^{*} \mathrm{p}<0.1$.

random: They are more likely to settle in provinces where support for the PSOE is on the rise. On the other hand, the OLS estimates are downward biased for regular immigration, suggesting that regular migrants tend to settle in provinces in which the electoral support for the PSOE is lower.

\subsection{Immigration and Votes for the Far-Right and the Far-Left}

Until 2015, the national political battle was dominated by the two major political parties that had governed Spain since the early eighties: the PP and the PSOE. However, the dominance of the two main parties was challenged by the incursion into the political arena of new parties from both sides of the ideological spectrum: VOX on the right and Podemos on the left. We check the robustness of the previous results to the impact that the rise of political competition exerted by these more extreme political forces might have had since the 2015 elections. We are especially interested in testing whether the emergence of VOX, a far-right political party that advocates for new immigration policies and stricter law enforcement against undocumented immigrants, is changing the observed distribution of votes. On the left, Podemos emerged almost simultaneously in national elections, competing with the socialist PSOE. The discourse on immigration in right-wing parties is clearly differentiated from left-wing parties' discourse, but it is hard to disentangle whether VOXs support in the polls is due to its anti-immigration narrative or to other confounding factors, such as concerns regarding the independence of Catalonia.

To check the robustness of our results we simply aggregate the vote shares of the two political parties from the right (PP plus VOX) and from the left (PSOE plus Podemos) and analyze them in Tables 6 and 7, respectively. We find that including VOX does not alter one of the previous results: namely that irregular immigration has a positive impact on the votes for right-wing parties. However, and in contrast to our previous findings, the new estimation suggests that regular immigrants do have a negative and significant impact on the support for the right. Regarding the results for the left, we find that an increase in regular immigration does not have any significant effect on the share of votes for the PSOE or Podemos. This is surprising, as our previous specification suggested that regular immigration had a strong positive effect on the PSOE's vote share. This result implies that increased political competition from the left has reduced the political gains that the PSOE garnered from regular immigration. 
Table 4. OLS impact of immigration on the share of votes for the PSOE.

\begin{tabular}{|c|c|c|c|c|c|c|}
\hline & (1) & $(2)$ & (3) & (4) & (5) & (6) \\
\hline$\Delta$ Share of irregular immigrants & $\begin{array}{l}6.278^{* * *} \\
(1.100)\end{array}$ & $\begin{array}{l}2.114 * * \\
(0.796)\end{array}$ & $\begin{array}{l}2.342 * * * \\
(0.743)\end{array}$ & $\begin{array}{l}2.380 * * * \\
(0.701)\end{array}$ & $\begin{array}{l}2.424 * * * \\
(0.704)\end{array}$ & $\begin{array}{l}2.712^{* * *} \\
(0.730)\end{array}$ \\
\hline$\Delta$ Share of regular immigrants & $\begin{array}{c}2.204 \\
(2.017)\end{array}$ & $\begin{array}{c}0.513 \\
(0.959)\end{array}$ & $\begin{array}{l}0.00955 \\
(0.818)\end{array}$ & $\begin{array}{l}0.00681 \\
(0.883)\end{array}$ & $\begin{array}{c}-0.0296 \\
(0.887)\end{array}$ & $\begin{array}{c}0.0778 \\
(0.875)\end{array}$ \\
\hline$\Delta$ Unemployment rate & & & $\begin{array}{c}0.00397^{* *} \\
(0.00154)\end{array}$ & $\begin{array}{c}0.00400^{* *} \\
(0.00156)\end{array}$ & $\begin{array}{l}0.00392 * * \\
(0.00148)\end{array}$ & $\begin{array}{c}0.00372 * * \\
(0.00165)\end{array}$ \\
\hline$\Delta$ Log GDP per capita & & & $\begin{array}{l}-0.0475^{* * *} \\
(0.0105)\end{array}$ & $\begin{array}{l}-0.0367 * * \\
(0.0142)\end{array}$ & $\begin{array}{l}-0.0355^{* *} \\
(0.0153)\end{array}$ & $\begin{array}{l}-0.0327^{* *} \\
(0.0153)\end{array}$ \\
\hline$\Delta$ Share of younger than 25 & & & & $\begin{array}{l}-1.057 \\
(1.274)\end{array}$ & $\begin{array}{l}-1.072 \\
(1.312)\end{array}$ & $\begin{array}{l}-1.069 \\
(1.314)\end{array}$ \\
\hline$\Delta$ Share of older than 65 & & & & $\begin{array}{l}-0.566 \\
(0.922)\end{array}$ & $\begin{array}{l}-0.514 \\
(0.845)\end{array}$ & $\begin{array}{l}-0.308 \\
(0.844)\end{array}$ \\
\hline$\Delta$ Share of high school dropouts & & & & & $\begin{array}{l}-0.110 \\
(0.125)\end{array}$ & $\begin{array}{l}-0.136 \\
(0.130)\end{array}$ \\
\hline$\Delta$ Share of highly educated & & & & & $\begin{array}{l}-0.155 \\
(0.240)\end{array}$ & $\begin{array}{c}-0.166 \\
(0.233)\end{array}$ \\
\hline$\Delta$ Share of workers in agriculture & & & & & & $\begin{array}{c}0.00189 \\
(0.00186)\end{array}$ \\
\hline$\Delta$ Share of workers in construction & & & & & & $\begin{array}{l}-0.00244 \\
(0.00275)\end{array}$ \\
\hline$\Delta$ Share of workers in industry & & & & & & $\begin{array}{c}0.00232 \\
(0.00190)\end{array}$ \\
\hline Year FE & NO & YES & YES & YES & YES & YES \\
\hline $\mathrm{N}$ & 200 & 200 & 200 & 200 & 200 & 200 \\
\hline
\end{tabular}

Notes: The dependent variable is the change in the share of votes for the PSOE between two consecutive presidential elections. Significance levels are denoted by $* * * p<0.01,{ }^{* *} p<0.05, * p<0.1$.

Table 5. IV impact of immigration on the share of votes for the PSOE.

\begin{tabular}{|c|c|c|c|c|c|c|}
\hline & (1) & (2) & (3) & (4) & (5) & (6) \\
\hline$\Delta$ Share of irregular immigrants & $\begin{array}{l}-1.594 \\
(2.028)\end{array}$ & $\begin{array}{l}-0.113 \\
(1.174)\end{array}$ & $\begin{array}{l}-0.551 \\
(1.362)\end{array}$ & $\begin{array}{l}-0.662 \\
(1.349)\end{array}$ & $\begin{array}{l}-0.664 \\
(1.367)\end{array}$ & $\begin{array}{l}-0.565 \\
(1.460)\end{array}$ \\
\hline$\Delta$ Share of regular immigrants & $\begin{array}{l}10.41 * * \\
(4.870)\end{array}$ & $\begin{array}{l}3.324 * * * \\
(0.804)\end{array}$ & $\begin{array}{l}3.040 * * * \\
(0.979)\end{array}$ & $\begin{array}{l}3.227^{* * *} \\
(0.940)\end{array}$ & $\begin{array}{l}3.036^{* * *} \\
(0.958)\end{array}$ & $\begin{array}{l}3.066^{* * * *} \\
(0.984)\end{array}$ \\
\hline$\Delta$ Unemployment rate & & & $\begin{array}{l}0.00379 * * * \\
(0.00142)\end{array}$ & $\begin{array}{l}0.00368^{* *} \\
(0.00144)\end{array}$ & $\begin{array}{l}0.00364^{* * *} \\
(0.00139)\end{array}$ & $\begin{array}{l}0.00381^{* * *} \\
(0.00147)\end{array}$ \\
\hline$\Delta$ Log GDP per capita & & & $\begin{array}{l}-0.0359 * * * \\
(0.0131)\end{array}$ & $\begin{array}{l}-0.0313 * * \\
(0.0158)\end{array}$ & $\begin{array}{l}-0.0304 * \\
(0.0164)\end{array}$ & $\begin{array}{l}-0.0279 * \\
(0.0165)\end{array}$ \\
\hline$\Delta$ Share of younger than 25 & & & & $\begin{array}{c}0.154 \\
(1.448)\end{array}$ & $\begin{array}{c}0.121 \\
(1.487)\end{array}$ & $\begin{array}{c}0.0996 \\
(1.486)\end{array}$ \\
\hline$\Delta$ Share of older than 65 & & & & $\begin{array}{l}-1.298 \\
(0.945)\end{array}$ & $\begin{array}{l}-1.237 \\
(0.878)\end{array}$ & $\begin{array}{l}-1.137 \\
(0.897)\end{array}$ \\
\hline$\Delta$ Share of high school dropouts & & & & & $\begin{array}{c}-0.0859 \\
(0.115)\end{array}$ & $\begin{array}{l}-0.105 \\
(0.115)\end{array}$ \\
\hline$\Delta$ Share of highly educated & & & & & $\begin{array}{l}-0.121 \\
(0.227)\end{array}$ & $\begin{array}{l}-0.109 \\
(0.223)\end{array}$ \\
\hline$\Delta$ Share of workers in agriculture & & & & & & $\begin{array}{c}0.00143 \\
(0.00187)\end{array}$ \\
\hline$\Delta$ Share of workers in construction & & & & & & $\begin{array}{c}-0.000584 \\
(0.00287)\end{array}$ \\
\hline$\Delta$ Share of workers in industry & & & & & & $\begin{array}{c}0.00269 \\
(0.00184)\end{array}$ \\
\hline Year FE & NO & YES & YES & YES & YES & YES \\
\hline K.-P. rk Wald F statistic & 9.407 & 11.59 & 15.62 & 20.78 & 18 & 11.67 \\
\hline $\mathrm{N}$ & 200 & 200 & 200 & 200 & 200 & 200 \\
\hline
\end{tabular}

Notes: The dependent variable is the change in the share of votes for the PSOE between two consecutive presidential elections. Significance levels are denoted by $* * * p<0.01,{ }^{* *} p<0.05,{ }^{*} p<0.1$. 
Table 6. IV impact of immigration on the share of votes for the right (PP + VOX).

\begin{tabular}{|c|c|c|c|c|c|c|}
\hline & (1) & (2) & (3) & (4) & (5) & (6) \\
\hline$\Delta$ Share of irregular immigrants & $\begin{array}{l}15.52^{* * *} \\
(2.598)\end{array}$ & $\begin{array}{r}5.882^{*} \\
(3.333)\end{array}$ & $\begin{array}{l}6.138^{* *} \\
(3.113)\end{array}$ & $\begin{array}{r}5.691 * \\
(3.190)\end{array}$ & $\begin{array}{c}5.620^{*} \\
(3.163)\end{array}$ & $\begin{array}{c}5.920^{*} \\
(3.524)\end{array}$ \\
\hline$\Delta$ Share of regular immigrants & $\begin{array}{l}-8.477^{* * *} \\
(2.855)\end{array}$ & $\begin{array}{c}-3.547^{*} \\
(2.101)\end{array}$ & $\begin{array}{l}-5.204^{* *} \\
(2.050)\end{array}$ & $\begin{array}{l}-4.278^{* *} \\
(1.839)\end{array}$ & $\begin{array}{l}-4.087^{* *} \\
(1.997)\end{array}$ & $\begin{array}{l}-3.875^{*} \\
(2.047)\end{array}$ \\
\hline$\Delta$ Unemployment rate & & & $\begin{array}{r}0.000209 \\
(0.00344)\end{array}$ & $\begin{array}{c}-0.000243 \\
(0.00321)\end{array}$ & $\begin{array}{c}0.000266 \\
(0.00330)\end{array}$ & $\begin{array}{c}-0.000236 \\
(0.00328)\end{array}$ \\
\hline$\Delta$ Log GDP per capita & & & $\begin{array}{l}-0.100 * * * \\
(0.0263)\end{array}$ & $\begin{array}{l}-0.130 * * * \\
(0.0425)\end{array}$ & $\begin{array}{l}-0.134 * * * \\
(0.0433)\end{array}$ & $\begin{array}{l}-0.136 * * * \\
(0.0435)\end{array}$ \\
\hline$\Delta$ Share of younger than 25 & & & & $\begin{array}{c}4.518 \\
(3.193)\end{array}$ & $\begin{array}{c}4.563 \\
(3.207)\end{array}$ & $\begin{array}{c}4.868 \\
(3.198)\end{array}$ \\
\hline$\Delta$ Share of older than 65 & & & & $\begin{array}{l}-1.110 \\
(1.755)\end{array}$ & $\begin{array}{l}-0.960 \\
(1.720)\end{array}$ & $\begin{array}{l}-0.828 \\
(1.750)\end{array}$ \\
\hline$\Delta$ Share of high school dropouts & & & & & $\begin{array}{c}0.0285 \\
(0.187)\end{array}$ & $\begin{array}{c}0.0363 \\
(0.203)\end{array}$ \\
\hline$\Delta$ Share of highly educated & & & & & $\begin{array}{c}0.341 \\
(0.309)\end{array}$ & $\begin{array}{c}0.325 \\
(0.310)\end{array}$ \\
\hline$\Delta$ Share of workers in agriculture & & & & & & $\begin{array}{c}-0.00268 \\
(0.00374)\end{array}$ \\
\hline$\Delta$ Share of workers in construction & & & & & & $\begin{array}{c}-0.00283 \\
(0.00647)\end{array}$ \\
\hline$\Delta$ Share of workers in industry & & & & & & $\begin{array}{r}0.000141 \\
(0.00425)\end{array}$ \\
\hline Year FE & NO & YES & YES & YES & YES & YES \\
\hline R-squared & -0.030 & 0.487 & 0.515 & 0.522 & 0.524 & 0.523 \\
\hline K.-P. rk Wald F statistic & 9.407 & 11.59 & 15.62 & 20.78 & 18 & 11.67 \\
\hline $\mathrm{N}$ & 200 & 200 & 200 & 200 & 200 & 200 \\
\hline
\end{tabular}

Notes: The dependent variable is the change in the share of votes for the right (PP) and the far-right (VOX) between two consecutive presidential elections. Significance levels are denoted by $* * * p<0.01,{ }^{* *} p<0.05, * p<0.1$. 
Table 7. IV impact of immigration on the share of votes for the left (PSOE + Podemos).

\begin{tabular}{|c|c|c|c|c|c|c|}
\hline & (1) & $(2)$ & (3) & (4) & (5) & (6) \\
\hline$\Delta$ Share of irregular immigrants & $\begin{array}{c}-13.94 * * * \\
(1.606)\end{array}$ & $\begin{array}{c}-1.972 \\
(1.253)\end{array}$ & $\begin{array}{c}-2.251^{*} \\
(1.253)\end{array}$ & $\begin{array}{c}-2.175^{*} \\
(1.300)\end{array}$ & $\begin{array}{c}-2.154^{*} \\
(1.286)\end{array}$ & $\begin{array}{c}-2.100 \\
(1.395)\end{array}$ \\
\hline$\Delta$ Share of regular immigrants & $\begin{array}{l}8.048^{* * *} \\
(2.998)\end{array}$ & $\begin{array}{c}0.191 \\
(0.952)\end{array}$ & $\begin{array}{c}-0.0608 \\
(0.954)\end{array}$ & $\begin{array}{c}-0.155 \\
(1.079)\end{array}$ & $\begin{array}{c}-0.214 \\
(1.106)\end{array}$ & $\begin{array}{c}-0.179 \\
(1.116)\end{array}$ \\
\hline$\Delta$ Unemployment rate & & & $\begin{array}{c}0.00251 \\
(0.00161)\end{array}$ & $\begin{array}{c}0.00258 \\
(0.00159)\end{array}$ & $\begin{array}{c}0.00243 \\
(0.00158)\end{array}$ & $\begin{array}{c}0.00268 \\
(0.00165)\end{array}$ \\
\hline$\Delta$ Log GDP per capita & & & $\begin{array}{l}-0.0276 * * \\
(0.0129)\end{array}$ & $\begin{array}{l}-0.0407^{* *} \\
(0.0182)\end{array}$ & $\begin{array}{c}-0.0395^{* *} \\
(0.0184)\end{array}$ & $\begin{array}{l}-0.0373 * * \\
(0.0183)\end{array}$ \\
\hline$\Delta$ Share of younger than 25 & & & & $\begin{array}{c}0.699 \\
(1.628)\end{array}$ & $\begin{array}{c}0.685 \\
(1.641)\end{array}$ & $\begin{array}{c}0.658 \\
(1.641)\end{array}$ \\
\hline$\Delta$ Share of older than 65 & & & & $\begin{array}{l}1.746^{* *} \\
(0.890)\end{array}$ & $\begin{array}{l}1.703^{* *} \\
(0.842)\end{array}$ & $\begin{array}{l}1.759 * * \\
(0.892)\end{array}$ \\
\hline$\Delta$ Share of high school dropouts & & & & & $\begin{array}{l}-0.00984 \\
(0.124)\end{array}$ & $\begin{array}{c}-0.0249 \\
(0.122)\end{array}$ \\
\hline$\Delta$ Share of highly educated & & & & & $\begin{array}{c}-0.103 \\
(0.199)\end{array}$ & $\begin{array}{c}-0.0867 \\
(0.200)\end{array}$ \\
\hline$\Delta$ Share of workers in agriculture & & & & & & $\begin{array}{c}0.00118 \\
(0.00202)\end{array}$ \\
\hline$\Delta$ Share of workers in construction & & & & & & $\begin{array}{c}-9.71 e-06 \\
(0.00314)\end{array}$ \\
\hline$\Delta$ Share of workers in industry & & & & & & $\begin{array}{c}0.00245 \\
(0.00206)\end{array}$ \\
\hline Year FE & NO & YES & YES & YES & YES & YES \\
\hline R-squared & -0.366 & 0.822 & 0.826 & 0.830 & 0.830 & 0.832 \\
\hline K.-P. rk Wald F statistic & 9.407 & 11.59 & 15.62 & 20.78 & 18 & 11.67 \\
\hline $\mathrm{N}$ & 200 & 200 & 200 & 200 & 200 & 200 \\
\hline
\end{tabular}

Notes: The dependent variable is the change in the share of votes for the left (PSOE) and the far-left (Podemos) between two consecutive presidential elections. Significance levels are denoted by $* * * p<0.01, * * p<0.05, * p<0.1$.

\section{Conclusion}

The political impact of immigration is under scrutiny in many countries. The literature reveals a consistent pattern across countries, whereby immigration favors rightleaning political parties that defend heavy-handed policies. Spain was considered an exception in the European context, as previous evidence indicated that immigration yielded a political premium to the left. In this article, we claim that distinguishing between documented and undocumented migration is key to understanding voters' responses in national elections. Previous literature has shown that undocumented immigrants consume less, earn lower wages, and are concentrated in specific regions, sectors, and occupations. We argue that irregular immigration is unlikely to affect natives through the labor market. However, there might be other reasons why voters might react to irregular migration. For instance, since undocumented immigrants are relegated to working in the informal sector, they cannot contribute to the welfare state with direct taxes, though they are often allowed to benefit from public health care and education. In addition, voters might respond to non-economic factors and to the indirect effects of irregular immigration when immigrants are concentrated in areas with a low supply of public services, thus, changing the compositional amenities of the neighborhoods.

We find that an increase in undocumented immigration increases support for the right-leaning PP and has no effect on the vote share of the PSOE. In contrast, a rise in the share of regular immigrants does not increase support for the PP while it does increase the vote share of the PSOE. Moreover, when we take into consideration the emergence of VOX and Podemos in electoral competitions, we observe that rising undocumented migration favors political support for the right and reduces support for the left, and conversely, that increasing documented migration reduces support for the right but does not affect support for the left. This evidence suggests that the rise of irregular immigration is being capitalized on by the right and not by the left, thereby refuting the idea that undocumented migration is polarizing society. This result is in line with others, such as Dustmann et al. (2019), who, instead of using the IV approach, employ a quasi-random allocation of immigrant refugees across locations in Denmark. Our findings complement previous evidence and open the door for further research on why voters react differently to regular versus irregular immigration. 


\section{Acknowledgments}

José L. Groizard acknowledges support from grant RTI2018-101696-B-100-R (MCl/AEI/FEDER, UE).

\section{Conflict of Interests}

The authors declare no conflict of interests.

\section{References}

Albert, C. (2021). The labor market impact of immigration: Job creation versus job competition. American Economic Journal: Macroeconomics, 13(1), 35-78. https://doi.org/10.1257/mac.20190042

Alonso-Borrego, C., Garoupa, N., \& Vázquez, P. (2012). Does immigration cause crime? Evidence from Spain. American Law and Economics Review, 14(1), 165-191. https://doi.org/10.1093/aler/ahr019

Barone, G., D'Ignazio, A., de Blasio, G., \& Naticchioni, P. (2016). Mr. Rossi, Mr. Hu and politics. The role of immigration in shaping natives' voting behavior. Journal of Public Economics, 136, 1-13. https://doi.org/ 10.1016/j.jpubeco.2016.03.002

Bertoli, S., \& Fernández-Huertas Moraga, J. (2013). Multilateral resistance to migration. Journal of Development Economics, 102, 79-100. https://doi.org/ 10.1016/j.jdeveco.2012.12.001

Card, D. (2001). Immigrant Inflows, native outflows, and the local labor market impacts of higher immigration. Journal of Labor Economics, 19(1), 22-64. https:// doi.org/10.1086/209979

Chalfin, A. (2014). What is the contribution of Mexican immigration to US crime rates? Evidence from rainfall shocks in Mexico. American Law and Economics Review, 16(1), 220-268. https://doi.org/ 10.1093/aler/aht019

Collado, M. D., Iturbe-Ormaetxe, I., \& Valera, G. (2004). Quantifying the impact of immigration on the Spanish Welfare State. International Tax and Public Finance, 11(3), 335-353. https://doi.org/10.1023/B: ITAX.0000021975.20256.ff

Dennison, J., \& Geddes, A. (2019). A rising tide? The salience of immigration and the rise of antiimmigration political parties in Western Europe. Political Quarterly, 90(1), 107-116. https://doi.org/ 10.1111/1467-923X.12620

Dennison, J., \& Mendes, M. (2019). When do populist radical right parties succeed? Salience, stigma, and the case of the end of Iberian 'exceptionalism' (Research Paper No. RSCAS 2019/26). Robert Schuman Centre for Advanced Studies. https://doi.org/10.2139/ssrn. 3372847

Donoso, V., Martín, V., \& Minondo, A. (2015). Do differences in the exposure to chinese imports lead to differences in local labour market outcomes? An analysis for spanish provinces. Regional Studies, 49(10), 1746-1764. https://doi.org/10.1080/
00343404.2013 .879982

Dustmann, C., Fasani, F., \& Speciale, B. (2017). Illegal migration and consumption behavior of immigrant households. Journal of the European Economic Association, 15(3), 654-691. https://doi.org/ 10.1093/jeea/jvw017

Dustmann, C., \& Frattini, T. (2014). The fiscal effects of immigration to the UK. Economic Journal, 124(580), F593-F643. https://doi.org/10.1111/ecoj.12181

Dustmann, C., \& Preston, I. P. (2007). Racial and economic factors in attitudes to immigration. B.E. Journal of Economic Analysis and Policy, 7(1), Article 62. https://doi.org/10.2202/1935-1682.1655

Dustmann, C., Vasiljeva, K., \& Piil Damm, A. (2019). Refugee migration and electoral outcomes. The Review of Economic Studies, 86(5), 2035-2091. https://doi.org/10.1093/restud/rdy047

Edo, A., Giesing, Y., Öztunc, J., \& Poutvaara, P. (2019). Immigration and electoral support for the far-left and the far-right. European Economic Review, 115, 99-143. https://doi.org/10.1016/j.euroecorev.2019. 03.001

Gálvez-Iniesta, I. (2020). The Size, socio-economic composition and fiscal implications of the irregular immigration in Spain. https://drive.google.com/ file/d/1SHDXCyKOy3vsycGQqAanME8Y_WHIpyu7/ view? usp=sharing

Glaeser, E. L. (2005). The political economy of hatred. The Quarterly Journal of Economics, 120(1), 45-86. https://doi.org/10.1162/0033553053327434

González Ferrer, A., \& Cebolla Boado, H. (2008). La inmigración en España 2000-2007 [Immigration in Spain 2000-2007]. Centro de Estudios Políticos y Constitucionales. http://hdl.handle.net/10261/93165

González, L., \& Surovtseva, T. (2020). Do more tourists promote local employment? (Working Paper No. 1208). BGSE.

Halla, M., Wagner, A. F., \& Zweimüller, J. (2017). Immigration and voting for the far right. Journal of the European Economic Association, 15(6), 1341-1385. https://doi.org/10.1093/jeea/jvx003

Izquierdo, M., Jimeno, J. F., \& Lacuesta, A. (2015). Spain: From immigration to emigration? (Working Paper No. 1503). Banco de España. https://doi.org/ 10.2139/ssrn.2566723

Jandl, M., Vogel, D., \& Iglicka, K. (2008). Report on methodological issues. CLANDESTINO.

Mayda, A. M. (2006). Who is against immigration? Review of Economics and Statistics, 88(3), 510-530.

Mayda, A. M., Peri, G., \& Steingress, W. (2020). The political impact of immigration: Evidence from the United States. American Economic Journal: Applied Economics. Advance online publication. https://www. aeaweb.org/articles?id=10.1257/app.20190081\&\& from $=f$

Mccully, B. A. (2020). Immigrants, legal status, and illegal trade. Brett A. McCully. https://www.brettmccully. com/files/jmp.pdf 
Mendez, I., \& Cutillas, I. M. (2014). Has immigration affected Spanish presidential elections results? Journal of Population Economics, 27(1), 135-171. https:// doi.org/10.1007/s00148-013-0471-y

Monras, J., Vázquez-Grenno, J., \& Elias, F. (2020). Understanding the effects of granting work permits to undocumented immigrants (Working Paper No. 1228). Barcelona GSE.

OECD. (2013). The fiscal impact of immigration in OECD countries. https://doi.org/10.1787/migr_outlook2013-6-en

Orrenius, P. M., \& Zavodny, M. (2003). Do amnesty programs reduce undocumented immigration? Evidence from IRCA. Demography, 40(3), 437-450. https://doi. org/10.2307/1515154

Ottaviano, G. I. P., \& Peri, G. (2005). The economic value of cultural diversity: Evidence from US cities. Journal of Economic Geography, 6(1), 9-44. https://doi.org/ 10.1093/jeg/lbi002

Peri, G. (2016). Immigrants, productivity, and labor mar- kets. Journal of Economic Perspectives, 30(4), 3-30. https://doi.org/10.1257/jep.30.4.3

Preston, I. (2014). The effect of immigration on public finances. Economic Journal, 124(580), F569-F592. https://doi.org/10.1111/ecoj.12180

Rickardsson, J. (2021). The urban-rural divide in radical right populist support: The role of resident's characteristics, urbanization trends and public service supply. The Annals of Regional Science, 67, 211-242. https://doi.org/10.1007/s00168-021-01046-1

Roupakias, S., \& Chletsos, M. (2020). Immigration and far-right voting: Evidence from Greece. Annals of Regional Science, 65(3), 591-617. https://doi.org/ 10.1007/s00168-020-00996-2

Stock, J. H., Wright, J. H., \& Yogo, M. (2002). A survey of weak instruments and weak identification in generalized method of moments. Journal of Business \& Economic Statistics, 20(4), 518-529. https://doi.org/ $10.1198 / 073500102288618658$

\section{About the Authors}

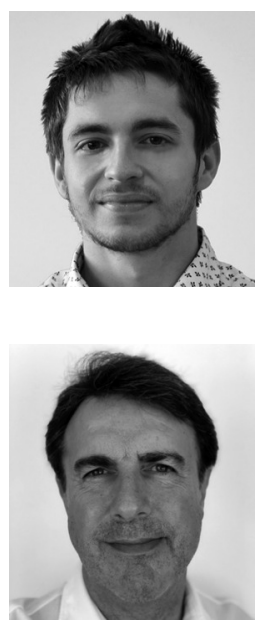

Ismael Gálvez-Iniesta is visiting professor at the University of the Balearic Islands, Spain. His research concentrates primarily on labor economics and immigration. He focuses on understanding the outcomes of frictional labor markets and how workers' and firms' choices determine the evolution of unemployment. In addition, recently he has been investigating the impact of immigration in the receiving country.

José L. Groizard is associate professor of international economics at the University of the Balearic Islands, Spain. His research interests include firm-level technology adoption, organizational aspects of production (e.g., FDI, offshoring), both at micro and macro-levels: tourism development and political conflict, international shocks and local development, trade frictions and migration linkages, and political economy of globalization. His research has appeared in European Economic Review, Economic Inquiry, Journal of Development Studies, The World Economy, among other journals. 